DOI https://doi.org/10.18551/rjoas.2021-02.06

\title{
THE INFLUENCE OF VARIOUS FACTORS OF ENTREPRENEURIAL BEHAVIOR ON DAIRY FARM BUSINESS PERFORMANCE IN BOYOLALI REGENCY, INDONESIA
}

\author{
Ayuningtyas Nilasari ${ }^{\star}$, Mukson, Edy Prasetyo \\ Faculty of Animal and Agriculture Sciences, University of Diponegoro, Semarang, Indonesia \\ *E-mail: Ayutyas853@gmail.com
}

\begin{abstract}
This study aims to analyze the factors that influence dairy farmers' entrepreneurial behavior and the influence of farmers' entrepreneurial behavior on the performance of dairy businesses in Boyolali Regency, Central Java, Indonesia. The number of samples in the study is 150 farmers in two-stage clustered random sampling. Data analysis uses Structural Equation Modeling (SEM) with the help of AMOS software. The results showed that there is a positive influence of technical factors, individual factors and environmental factors on entrepreneurial behavior. Technical factors, environmental factors and entrepreneurial behavior of farmers also have a positive effect on the performance of dairy businesses.
\end{abstract}

\section{KEY WORDS}

Technical factors, individual factors, environmental factors, dairy business, entrepreneurial behavior, livestock business performance.

Animal husbandry is a business carried out by some Indonesians as one of the sources of income. The breadth of potential in nature, especially in the availability of feed, is a support for business success in the field of animal husbandry. In fact, a few people try to develop through innovations both in technical cultivation and post-production processing support. Farms that become prima donnas in some areas, especially in Boyolali Regency, are dairy cows. According to Barokah (2009), dairy cows became an icon in Boyolali Regency because it is the largest milk producer in Central Java. This cannot be separated from the large role of the Boyolali regency government so far, both in efforts to spur the development of dairy farms and the dairy processing industry's development.

The dairy farming business in Boyolali Regency is carried out by most communities on a small business scale or people's farms. According to research, Rachman et al. (1999) in Barokah (2009), the dairy business is generally carried out by farmers with an average business scale of 3 heads per breeder, with productivity ranging from 10 to 14 liters/tail/day. Meanfafaatkan and maximize the available natural resources become an option so that farmers have a huge influence to determine livestock business development through the technical improvement of cultivation and follow-up business post-production.

The dairy farming business in Boyolali Regency is carried out by most communities on a small business scale or people's farms. According to research, Rachman et al. (1999) in Barokah (2009), the dairy business is generally carried out by farmers with an average business scale of 3 heads per breeder, with productivity ranging from 10 to 14 liters/tail/day. Utilizing and maximizing the available natural resources is an option so that farmers have a huge influence to determine their livestock business development through the technical improvement of cultivation and follow-up business post-production.

The problems faced in the dairy business are divided into three sectors, namely upstream, middle and downstream. The upstream sector's problems include low dairy productivity, lack of availability of dairy seedlings, high feed costs, small ownership scale, and low quality of human resources. The middle sector's problems include technical cultivation and low recording system, land availability for feed production decreases, conversion of agricultural land to non-agricultural, business capital from banking is still intense and cross-sectoral cooperation has not been integrated. Problems in the downstream sector include the price of fresh milk from producer farmers is still low, and the selling price of pedet / dairy cows is unstable (Mandaka and Hutagaol, 2005). Human resource development 
is expected to be one of the keys to answering this problem because, in the current era of globalization, creative and innovative farmers are needed to survive and compete.

Entrepreneurial factors determine the success of farmers in adjusting to environmental changes. This is what distinguishes livestock entrepreneurs from ordinary breeders. A livestock entrepreneur will consider various aspects of the market, see and manage possibilities, consider his business analysis, and have the management ability to develop his livestock business today so that better and profitable results are obtained. This is in line with Grande et al. (2012)'s statement that entrepreneurial behaviour can improve business performance and make farmers or ranchers innovative in utilizing their resources more efficiently.

\section{LITERATURE REVIEW}

Suryana (2003) explains the science of entrepreneurship is the ability and behaviour of a person is facing life's challenges and how to obtain opportunities with various risks that may be faced. Creative and innovative skills that serve as the basis, tips and resources to look for success opportunities. The point of entrepreneurship is creating different or new things through creative thinking and acting innovatively to create opportunities.

According to Bird (1996), entrepreneurial behaviour is human behaviour in identifying and exploiting opportunities through businesses' formation and development emphasising human creative and innovative behaviours. Performance can be used as a benchmark of success rate in making an effort to achieve the goals to be achieved. Good performance is a successful performance to achieve its goals well. The level of welfare in farmers can be directly affected by performance (Tajidan, 2013). Business performance is influenced by entrepreneurial behaviour as munizu research (2010) states that what affects the success of the business performance is more to human factors or the quality of resource improvements such as motivation, entrepreneurial competence, individual aspects, only after that other factors such as finance, access to capital and strategies run by farmers or farmers.

According to Premisti et al. (2016), dairy milk marketing is an important factor in pricing and ultimately determining the income of dairy milk producers. High prices do not necessarily provide high profits for manufacturers. Production needs to be considered marketing efficiency. The high cost of marketing will affect the price paid by consumers, and the price at the producer level makes the product able to compete in the market with the appropriate price and quality. It can do an increase in the dairy population in an area supported by the area's potential. It can enhance regional potentials for dairy development by providing feed availability, farmer knowledge, milk demand, farmers' income, market infrastructure, credit agencies' role, and local government policies (Santoso et al., 2013).

\section{METHODS OF RESEARCH}

This research is conducted in August-September 2020 in Boyolali Regency. The largest dairy population in Central Java is in Boyolali and it is the largest milk-producing centre in Central Java. The research was conducted by survey method, interview technique based on the questionnaire. The number of samples as many as 150 farmers in two stages clustered random sampling was carried out at two levels: the sub-district level and the farmer level. The sub-district level was deliberately selected four sub-districts, namely Musuk, Cepogo, Ampel and Mojosongo subdistricts. Data analysis using Structural Equation Modeling (SEM) AMOS software. Sem analyzed data processing includes validity and reliability tests, sample adequacy assumptions, normality assumptions, outlier assumptions, Goodness of Fit evaluations, and hypothesis testing.

\section{RESULTS AND DISCUSSIONS}

Boyolali Regency is one of 35 regencies/cities in Central Java Province, located between $110^{\circ} 22^{\prime}-110^{\circ} 50^{\prime}$ East Longitude and $7^{\circ} 7^{\prime}-7^{\circ} 36^{\prime}$ South Latitude, with an 
altitude between 75-1500 meters above sea level. The respondents' characteristics in Boyolali Regency are known that the male sex of $79.33 \%$ dominated the respondents' breeders. Most respondent breeders (60.67\%) are in the age range of $41-60$ years. The level of education of the respondent breeders is mostly $(39.33 \%)$ finished high school. The number of family members of farmers respondents is mostly $(70.67 \%)-7$ people. The number of lactation parents owned by respondent breeders is largely $(66.00 \%) 1-3$ tails. The number of bunting cows owned by farmers respondents was mostly $(67.33 \%) 1-3$ tails. The number of heifers owned by farmers is mostly $(51.33 \%)$ does not have a heifer. The number of farmers owned by respondents is mostly $(67.33 \%) 1-3$ tails. The number of bulls owned by the respondent breeders is largely (51.33\%) 1-3 tails. Milk production produces by farmers respondents (27.33\%) 10-<20 litres/day. Farmers' dairy business income is mostly (34.67\%) between Rp. 1,000,000 to Rp. 2,000,000,-. Farmers' income respondents mostly (42.00\%) between Rp. 1,000,000 to Rp. 2,000,000,-. Farmers who had other incomes mostly $(62.67 \%)$ have no other income.

The first step in processing Structural Equation Modeling (SEM) with AMOS is a validity test where the validity of the research construction can be seen from the value of the loading factor. The item is valid if the loading factor value is greater than $\geq 0.5$ or more ideally more than $\geq 0.7$ so that items with a loading factor of less than $\geq 0.50$ are considered invalid and not included in the measurement (Ghozali, 2017). Formal education construction has a loading factor of 0.491 . This construction is considered invalid so it must be removed from the model. Based on AVE and CR calculations, the entire construct has a value of AVE $>0.5$ and $C R>$ 0.7 , which means the entire construct has a good and reliable convergent. Based on normality testing, this c.r multivariate model is 2,248. Multivariate c.r is in the range of -2.58 $<z<2.58$, which means the SEM model in this study has met the normality assumption criteria. No Mahalanobis distance from the entire sample exceeded more than 51,178 (ChiSquare at $\alpha=0.001$ and $\mathrm{df}=24)$, meaning the data analyzed did not contain an outlier.

Table 1 - Validity and Construct Reliability Test Results (CR)

\begin{tabular}{lllll}
\hline \hline Variable & Indicator & Loading Factor & CR & AVE \\
\hline & FT1 & 0.780 & & \\
FT & FT2 & 0.920 & 0.939 & 0.757 \\
& FT3 & 0.836 & & \\
& FT4 & 0.895 & & \\
FI & FT5 & 0.910 & 0.831 & 0.622 \\
& FI2 & 0.795 & & \\
& FI3 & 0.733 & & \\
& FI4 & 0.834 & & \\
FL & FL1 & 0.791 & 0.934 & \\
& FL2 & 0.741 & & \\
& FL3 & 0.773 & & \\
& FL4 & 0.808 & & \\
& FL5 & 0.825 & & \\
PK & FL6 & 0.847 & 0.649 \\
& FL7 & 0.932 & & \\
& PK1 & 0.791 & & \\
& PK2 & 0.797 & & \\
KU & PK3 & 0.803 & 0.872 & \\
& PK4 & 0.757 & & \\
\hline
\end{tabular}

The next step is a model test of Goodness of fit evaluation Sem testing using AMOS software obtained the following models: 


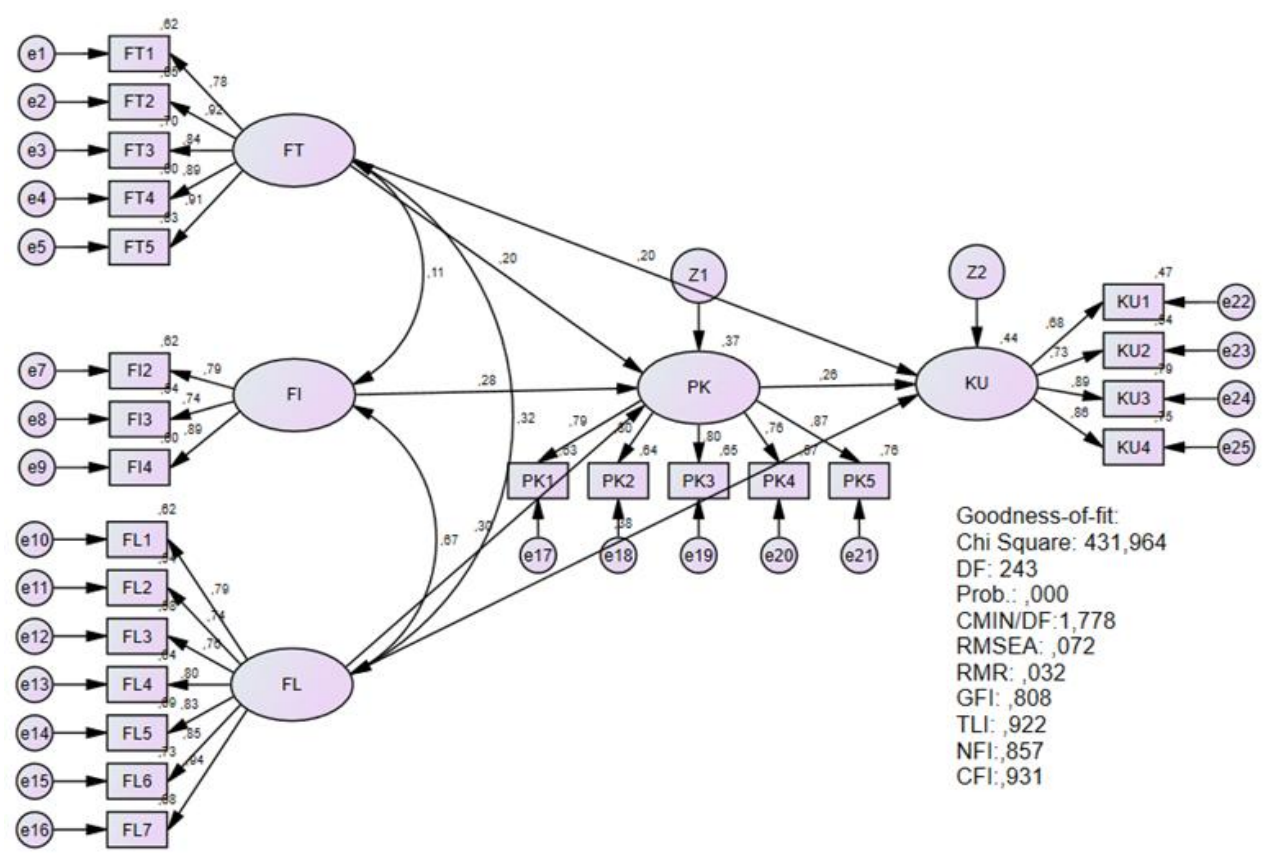

Figure 1 - Structural Model of Entrepreneurial Behavior to Livestock Business Performance

In Figure 1 Entrepreneurial behaviour variables can act as mediation variables between independent variables of environmental factors and livestock business performance variables. More details can be seen as an evaluation of the Goodness of Fit in Table 2.

Table 2 - The goodness of Fit Evaluation Results

\begin{tabular}{lllll}
\hline \hline No. & Index & Reference Value & Results & Evaluation \\
\hline 1. & Chi Square $\left(\mathrm{X}^{2}\right)$ & Expected small & 431,964 & - \\
2. & Probability & $>0.05$ & 0,000 & Poor fit \\
3. & CMIN/DF & $<2$ & 1,778 & Good fit \\
4. & RMSEA & $\leq 0.08$ & 0,072 & Good fit \\
5. & RMR & $<0.05$ & 0,032 & Good fit \\
6. & GFI & $\geq 0,9$ & 0,808 & Marginal fit \\
7. & TLI & $\geq 0,9$ & 0,922 & Good fit \\
8. & NFI & $\geq 0,9$ & 0,857 & Marginal fit \\
9. & CFI & $\geq 0,9$ & 0,931 & Good fit \\
\hline
\end{tabular}

Table 2 indicates the Goodness of fit the total value of Chi-Square (X2) is 431.964 with a probability of 0.000 .5 criteria show good fit results, namely CMIN/DF, RMSEA, RMR, TLI, and $\mathrm{CFI}$ where the value is at vulnerable reference values of $1,778,0.772,0.032,0.922$ and 0.931 . 2 criteria show marginal fit results namely GFI and NFI, GFI value of 0.808 and NFI value of 0.857 is close to the reference value so it can be said to be marginal fit. These results show that the goodness of fit models are considered to meet the suitability of the model. The results showed that all hypotheses are acceptable and valid. $\mathrm{H} 1, \mathrm{H} 3, \mathrm{H} 3, \mathrm{H} 4$ and $\mathrm{H} 6$ are valid at a significant level of $\alpha 0.001$ while $\mathrm{H} 5$ is valid at a significant level $\alpha 0.05$.

Table 3 - Structural Model Hypothesis Test Results

\begin{tabular}{cccccccc}
\hline \hline & Variable & & Estimate & S.E. & C.R. & P & Hypothesis \\
\hline PK & $<---$ & FT &, 166 &, 069 & 2,409 &, $016^{*}$ & H1 \\
PK & $<--$ & FI &, 226 &, 095 & 2,376 &, $018^{*}$ & H2 \\
PK & $<---$ & FL &, 262 &, 106 & 2,470 &, $014^{*}$ & H3 \\
KU & $<---$ & FT &, 161 &, 060 & 2,705 &, $007^{*}$ & H4 \\
KU & $<--$ & FL &, 305 &, 078 & 3,929 & $* * *$ & H5 \\
KU & $<---$ & PK &, 231 &, 085 & 2,723 &, $006^{*}$ & H6 \\
\hline
\end{tabular}

Description: **: significant on the $\alpha 0.001$; *: significant on the $\alpha 0.05$. 
Based on the hypothetical test results, it is known that technical factors (FT) have a positive influence on entrepreneurial behaviour (PK). This is indicated by a probability value less than $\alpha 0.05$, and a positive correlation is indicated by an estimated value of 0.166 . This means that the better the technical factors owned by dairy farmers, which is reflected in the indicators of the amount of forage feed, concentrate feeding, feed quality and lactation age, the higher the entrepreneurial behaviour of dairy farmers.

The analysis results showed a positive influence between individual factors (FI) on entrepreneurial behaviour (EB). This is indicated by a probability value $(P)$ less than $\alpha 0.05$, with an estimated value of 0.226 . This high estimate indicates that individual factors have a strong influence on the entrepreneurial behaviour of dairy farmers. The experience of farmers in dairy business makes farmers more adept at predicting the chances of success and failure in the dairy business. With the increasing experience of farmers, the courage to take risks is higher because farmers easily map the opportunities and obstacles faced when doing livestock business. The experience of farmers can be seen from the way of livestock maintenance in maintaining the health of dairy cattle, treatment if livestock is sick, the fulfilment of animal feed needs, determination of the right time for artificial insemination, characteristics of livestock that can produce milk with good quantity and quality.

Based on the hypothetical test results, it is known that technical factors (TF) have a positive influence on livestock business performance (BP). This is indicated by a probability value less than $\alpha 0.05$, and a positive correlation is indicated by an estimated value of 0.166 . Land ownership is to be made into cages of dairy cows influences farmers' income, productivity, and commitment to run their dairy businesses. The commitment is formed because of the fores looking in the farmer itself to expand and develop his dairy business so that the area of the cage owned by farmers has a positive relationship to the dairy business's performance.' Based on the hypothesis testing results, there is a positive influence between entrepreneurial behaviour (EB) and Livestock Business Performance (BP). This is indicated by a probability value $(P)$ less than $\alpha 0.05$, with an estimated value of 0.231 . This can mean that the more farmers behave diligently, responsive to opportunities, independent, dare to take risks, and innovative, it will affect livestock businesses' performance, including increasing income, increasing productivity, increasing competitive ability, and high commitment to the business carried out. This is in line with Roach et al., (2016) research shows a positive relationship between entrepreneurial behaviour to a business performance where entrepreneurial factors that influence business performance and innovation are important factors to improve business performance.

\section{CONCLUSION}

Technical factors, individual factors, and environmental factors all three have a significant influence on dairy businesses' entrepreneurial behaviour. Technical factors affect the performance of the dairy business. Indicators that reflect technical factors that affect dairy businesses' performance are the amount of forage feed, concentrate feed provided, the quality of dairy feed, lactation life, and land area for the maintenance of dairy cows. Environmental factors affect the performance of a dairy business. Indicators that reflect environmental factors that affect dairy farmers' performance are the availability of input materials, counselling and training, capital and saprotan assistance, promotion and marketing support, business regulation, farmer cohesion and access to market information. Entrepreneurial behaviour has a significant effect on the performance of dairy businesses. Indicators that reflect entrepreneurial behaviour that affects dairy farmers' performance are innovative, dare to take risks, diligently strive, respond to opportunities, and be independent.

\section{REFERENCES}

1. Awan, J.S., A. Atabany and B.P. Purwanto. 2016. Pengaruh umur beranak pertama terhadap performa produksi susu sapi friesian holstein di BBPTU-HPT Baturraden. Jurnal Ilmu Produksi and Teknologi Hasil Peternakan 04(2): 306-311. 
2. Badan Pusat Statistik. 2019. Kabupaten Boyolali Dalam Angka 2019. Kabupaten Boyolali.

3. Barokah, U. 2009. Strategi pengembangan usaha peternakan sapi perah rakyat di Kabupaten Boyolali. Jurnal Sains Peternakan ISSN 1693-8828 7(2): 80-86.

4. Bird MJ. 1996. Enterpreneurial Behaviour. McGraw-Hill Irwin. Singapore.

5. Doye, N. C., and Bwisa, M. (2015). The relationship between entrepreneurial behavior and performance of camel rearing enterprises In Turkana County, Kenya. International Journal of Technology Enhancements and Engineering Research, 3(09), 149-157.

6. Ghozali, I. 2017. Model Persamaan Struktural Konsep and Aplikasi dengan Program AMOS 24.0. Badan Penerbit Universitas Diponegoro. Semarang.

7. Grande, J., E Medsen, \& OJ Borch. (2012). The relationship between resources, entrepreneurial orientation and performance in farm-based ventures. International Journal of Enterpreneurship and Regional Development, 23(3-4).

8. Mandaka, S. and M. P. Hutagaol. 2005. Analisis fungsi keuntungan, efisiensi ekonomi and kemungkinan skema kredit bagi pengembangan skala usaha peternakan sapi perah rakyat Di Kelurahan Kebon Pedes, Kota Bogor. Jurnal Agro Ekonomi 23: 191-208.

9. Mukson, T. Ekowati, M. Handayani, and D. W. Harjanti. 2009. Faktor-faktor yang mempengaruhi kinerja usaha ternak sapi perah rakyat Di Kecamatan Getasan Kabupaten Semarang. Dalam: Prosiding Seminar Nasional Kebangkitan Peternakan. Magister Ilmu Ternak. Semarang 20 Mei 2009. Fakultas Peternakan Universitas Diponegoro. Hal: 25-37.

10. Premisti, P.U.L, A. Setiadi and W. Sumekar. 2016. Pemasaran susu Di Kecamatan Mojosongo Kecamatan Cepogo Boyolali. FPP UNDIP. Jurnal Mediagro 12(1): 27-34.

11. Puspitasari. 2013. Pengaruh Perilaku Kewirausahaan Petani Anggrek Terhadap Kinerja Usaha: Kasus di Kecamatan Gunung Sindur and Parung Kabupaten Bogor and Kecamatan Serpong, Kota Tangerang Selatan. Laporan Penelitian. Institut Pertanian Bogor. Bogor.

12. Rahayu, E.T. 2013. Analisis pendapatan usaha ternak sapi perah Di Kecamatan Cepogo Kabupaten Boyolali. Jurnal Sains Peternakan 11 (2): 99-105.

13. Rahmi K. 2016. Pengaruh Perilaku Kewirausahaan Petani Terhadap Kinerja Usaha Pada Sistem Integrasi Tanaman and Ternak (Kasus:Di Kabupaten Lima Puluh Kota Provinsi Sumatera Barat). Laporan Penelitian. Institut Pertanian Bogor. Bogor.

14. Roach, D. C., Ryman, J. A., \& Joyline, M. (2016). Effectuation, innovation and performance in SMEs: an empirical study. European Journal of Innovation Management, 19(2), 214-238. https://doi.org/10.1108/EJIM-12-2014-0119.

15. Rusdiana, S., and Praharani, Lisa. 2010. Profil and Profitabilitas Usaha Ternak Sapi Perah Di Desa Jelok Kecamatan Cepogo Kabupaten Boyolali. Pusat Penelitian and Pengembangan Peternakan. Badan Penelitian and Pengembangan Pertanian

16. Santosa, Siswanto,. Agus Setiadi,. Ratih Wulandari. 2013. Analisis pengembangan usaha peternakan sapi perah dengan menggunakan paradigma agribisnis Di Kecamatan Musuk Kabupaten Boyolali. Buletin Peternakan Vol 32(2) Hal 125-135.

17. Soekartawi. (2006). Analisis Usahatani. Jakarta: UI Press.

18. Suryana. 2003. Kewirausahaan: Pedoman Praktis, Kiat, and Proses Menuju Sukses (Pertama). Salemba Empat. Jakarta.

19. Tajidan, 2013. Manajemen Rantai Pasok and Integrasi Proses Bisnis dalam Upaya Peningkatan Kesejahteraan Petani Jagungdi Provinsi Nusa Tenggara Barat. Disertasi. Malang. Program Pascasarjana Fakultas Pertanian. Universitas Brawijaya.

20. Zainura, U. 2016. Pengaruh Perilaku Kewirausahaan Terhadap Kinerja Usahatani Kopi Arabika Gayo di Kabupaten Bener Meriah Provinsi Aceh. Laporan Penelitian. Institut Pertanian Bogor. Bogor. 